\title{
EVALUATION OF THYROID SWELLINGS BY FNAC IN RIMS, SRIKAKULAM
}

\author{
Prasada Rao Dasari ${ }^{1}$, Suraj Kumar Pattnayak2 , Jagadish Namballa 3 , Dharma Kishore Raja Chenna 4
}

${ }^{1}$ Associate Professor, Department of Surgery, Rajiv Gandhi Institute of Medical Sciences, Srikakulam, Andhra Pradesh. ${ }^{2}$ Assistant Professor, Department of Surgery, Rajiv Gandhi Institute of Medical Sciences, Srikakulam, Andhra Pradesh. ${ }^{3}$ Assistant Professor, Department of Surgery, Rajiv Gandhi Institute of Medical Sciences, Srikakulam, Andhra Pradesh. ${ }_{4}^{4}$ Assistant Professor, Department of Surgery, Rajiv Gandhi Institute of Medical Sciences, Srikakulam, Andhra Pradesh.

\section{ABSTRACT}

\section{BACKGROUND}

Rajiv Gandhi Institute is located in backward district in Andhra Pradesh. This study attempts to evaluate the types of Thyroid swellings, epidemiological factors in comparison with data available in literature. Fine needle aspiration cytology is now widely accepted as simple, most cost effective, least non-invasive investigation with minimal complications. The aim of the study is to evaluate the thyroid swelling based on fine needle aspiration cytology.

\section{METHODS}

A prospective longitudinal study is done over a period of 1 year from 1st August 2015 to 31st July on patients attending with midline neck swelling to the Outpatient Department of General Surgery, RIMS, Srikakulam. FNAC has been done with 23-gauge needle, smear was fixed with $90 \%$ alcohol solution and stained with Papanicola ou's stain. Detailed history regarding present complaint and duration of swelling, features of hypo- or hyperthyroidism and family history of thyroid swelling, and the results were plotted in charts.

\section{RESULTS}

Total number of patients visited surgical OP : 10482

Patients with Thyroid swelling : $\quad: 129$

Male Patients $\quad: 8$

Female Patients $\quad: 121$

Male: Female $\quad: 1: 15.01$

Most commonly seen in age group : : $\quad 25$ to 35 yrs.

Most common type is Colloid goitre : $\quad(47 \%)$

Incidence of malignancy is 6\% (Papillary carcinoma 3\%, Follicular neoplasia 3\%) commonest age for malignant thyroid swelling: 35-50 yrs. Most common presenting complaint is swelling in front of the neck (100\%). Duration of swelling: 2 yrs. to 3 yrs. (63\%). Positive family history is seen in 14 patients (10.93\%).

\section{CONCLUSION}

Colloid goitre is more common benign thyroid selling. Thyroid disorders are more common in females. Most common in the age group of 25-40 yrs. Papillary carcinoma is most commonly seen. The high incidence of colloid goitre and increased incidence of follicular carcinoma increased prevalence of Thyroid swellings as suggested by positive family history could be due to high endemicity of iodine deficiency in Srikakulam district and surrounding areas.

\section{KEYWORDS}

FNAC, Colloid Goitre Carcinoma of Thyroid.

HOW TO CITE THIS ARTICLE: Dasari PR, Pattnayak SK, Namballa J, et al. Evaluation of thyroid swellings by FNAC in RIMS, Srikakulam. J. Evolution Med. Dent. Sci. 2016;5(72):5265-5267, DOI: 10.14260/jemds/2016/1193

\section{INTRODUCTION}

Thyroid swelling is a common neck swelling worldwide, though regional variations are seen in incidence and type of swelling. More common in countries like India, which is endemic for Iodine deficiency. ${ }^{1}$ Development of goitre is concern for both patient and clinician, as many of the thyroid swellings may turn malignant. Though most of the thyroid swellings are benign, prevalence of malignancy among the

Financial or Other, Competing Interest: None.

Submission 18-08-2016, Peer Review 30-08-2016,

Acceptance 01-09-2016, Published 07-09-2016.

Corresponding Author:

Dr. Prasada Rao Dasari,

Associate Professor,

Department of Surgery,

RIMS, Srikakulam-532001,

Andhra Pradesh.

E-mail: prasadrao.dasari@gmail.com

DOI: $10.14260 /$ jemds/2016/1193 solitary nodular goitre is $10 \%$.(2) Thyroid malignancy is the commonest endocrine malignancy. Papillary carcinoma is the most common followed by follicular, medullary, anaplastic and lymphoma. ${ }^{3}$ Fine Needle Aspiration Cytology (FNAC) is now being accepted as most cost effective, minimal invasive technique with very low incidence of complications in the diagnosis of thyroid lesions with an advantage of segregating the patients into operative and non-operative. ${ }^{4} \mathrm{~A}$ thyroid swelling which is usually considered for FNAC should be firm and palpable. FNAC can also be done on nodules suspicious on ultrasound: dominant or atypical nodules, dominant nodule of MNG, complex or cystic, recurrent nodules or any nodule associated with palpable cervical lymph nodes. ${ }^{5}$ FNAC is considered to be the "gold standard in selection of patients for surgery." (6)

\section{METHODS}

A prospective study was done over a period of $1 \mathrm{yr}$. from $1 \mathrm{st}$ August 2015 to 31st July on patients attending surgical OP of 
RIMS, Srikakulam. Patients with thyroid swelling with no other serious medical disorders were included. Patient's clinical features regarding present complaint, duration of swelling, any symptoms of hypo- or hyperthyroidism, pressure symptoms and family history. All the patients were evaluated for thyroid hormonal assay; 129 patients were included in the present study. FNAC was performed with 23-gauge needle smears were fixed with ether, 95\% alcohol solution and staining was performed with Papanicolaou's staining.

\section{RESULTS}

Patients with Thyroid swellings attended to RIMS General Hospital. From $1^{\text {st }}$ August 2015 - 31 st July 2016.

Male 8

Female 121

Total Number of Patients : 129

\begin{tabular}{|c|c|c|c|c|}
\hline Age & Males & Females & Number of Patients & $\mathbf{\%}$ \\
\hline 5-15 Yrs. & 2 & 4 & 6 & 4.65 \\
\hline 16-25 Yrs. & 1 & 26 & 27 & 20.93 \\
\hline 26-35 Yrs. & 0 & 40 & 40 & 31.01 \\
\hline 36-45 Yrs. & 1 & 26 & 27 & 20.93 \\
\hline 46-55 Yrs. & 2 & 16 & 18 & 13.95 \\
\hline 56-65 Yrs. & 2 & 7 & 9 & 6.98 \\
\hline 66 -75 Yrs. & 0 & 2 & 2 & 1.55 \\
\hline
\end{tabular}

Table 1: Age Distribution of Thyroid Swellings

\begin{tabular}{|c|c|c|}
\hline Lymphocytic Thyroiditis & 23 & 17.83 \\
\hline Multinodular Goitre & 17 & 13.18 \\
\hline Adenomatous Goitre & 20 & 15.50 \\
\hline Colloid Goitre & 61 & 47.29 \\
\hline Papillary Carcinoma & 4 & 3.10 \\
\hline Follicular Neoplasm & 4 & 3.10 \\
\hline Table 2: Types of Thyroid Swelling Based on FNAC
\end{tabular}

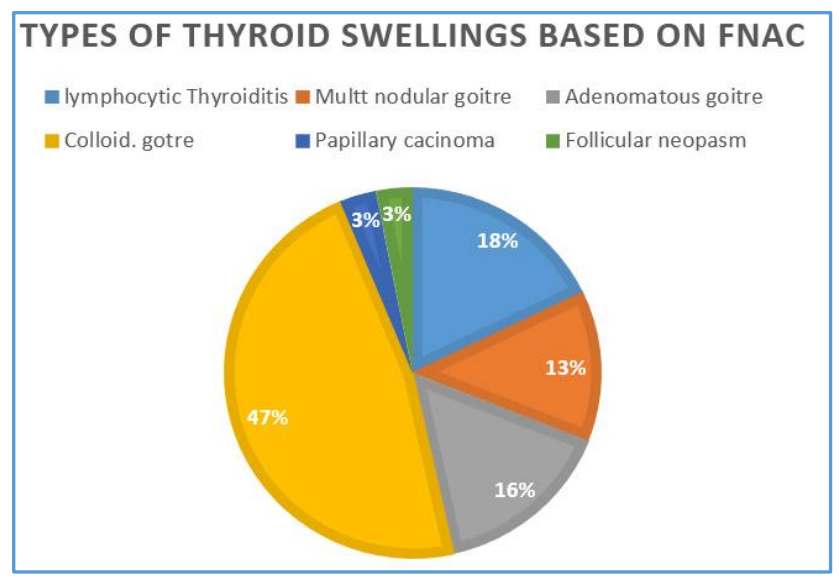

\begin{tabular}{|c|c|c|c|c|c|c|c|}
\hline $\begin{array}{c}\text { Types of } \\
\text { Thyroid } \\
\text { Swelling }\end{array}$ & \multicolumn{7}{|c|}{ Age Distribution of Thyroid Swelling } \\
\hline & $\begin{array}{c}\mathbf{5 - 1 5} \\
\text { Years }\end{array}$ & $\begin{array}{c}\mathbf{1 6 - 2 5} \\
\text { Years }\end{array}$ & $\begin{array}{c}\mathbf{2 6 - 3 5} \\
\text { Years }\end{array}$ & $\begin{array}{c}\mathbf{3 6 - 4 5} \\
\text { Years }\end{array}$ & $\begin{array}{c}\mathbf{4 6 - 5 5} \\
\text { Years }\end{array}$ & $\begin{array}{l}\mathbf{5 6 - 6 5} \\
\text { Years }\end{array}$ & $\begin{array}{c}\text { 66-75 } \\
\text { Years }\end{array}$ \\
\hline $\begin{array}{c}\text { Chronic } \\
\text { Lymphocytic } \\
\text { Thyroiditis }\end{array}$ & 1 & 4 & 9 & 6 & 3 & 0 & 0 \\
\hline $\begin{array}{c}\text { Adenomatous } \\
\text { Goitre }\end{array}$ & 1 & 5 & 3 & 8 & 2 & 1 & 0 \\
\hline $\begin{array}{c}\text { Multinodular } \\
\text { Goitre }\end{array}$ & 0 & 4 & 4 & 7 & 1 & 1 & 1 \\
\hline Colloid Goitre & 3 & 8 & 28 & 7 & 9 & 5 & 1 \\
\hline $\begin{array}{c}\text { Papillary } \\
\text { Carcinoma }\end{array}$ & 1 & 1 & 1 & 0 & 0 & 0 & 0 \\
\hline $\begin{array}{c}\text { Follicular } \\
\text { Neoplasia }\end{array}$ & 0 & 2 & 1 & 0 & 0 & 0 & 0 \\
\hline \multicolumn{7}{|c|}{ Table 3: Age Distribution of Thyroid Swelling } \\
\hline
\end{tabular}

\section{DISCUSSION}

In the present study most of the patients are in the age group of $25-35$ yrs. (47\%) and $51 \%$ of patients are in the age group of 25-40 yrs. with a median age of 32 yrs. Females are more commonly involved than males (M:F 1:15). Similar results were seen in study by Gardner HA et al 7 and by Sengupta et al ${ }^{8}$ and by study by Gole PR et al. ${ }^{9}$ As per literature, people are more susceptible to hormonal changes in the age group of 20 $40 \mathrm{yrs}$. leading to increased levels of thyroid binding globulin and increased requirements for iodine. This may be the cause for increased incidence of thyroid disorders in the age group. Colloid goitre is the most common benign condition in the present study. The results were similar to the study by Handa et $\mathrm{al}^{10}$ and Babu SBK et $\mathrm{al}^{11}$ and by Gole PR et al. ${ }^{9}$

Papillary carcinoma is the most common malignancy in our study. Though papillary carcinoma is common, incidence of follicular carcinoma is also similar to the incidence of papillary carcinoma, probably due to high prevalence of iodine deficiency goitre. Most of (100\%) the patients presented with swelling in front of the neck. Pressure symptoms are the next most common complaint followed by pain. Most patients presented within 2 yrs. of duration of their diseases. Sengupta et al reported that $93.2 \%$ patients presented with midline neck swelling and pain as the next most common symptom. The duration of complaints varied from 6 months to 3 yrs. In present study, $94.4 \%$ patients presented with euthyroid on thyroid hormonal profile similar to study by Sengupta et al and by Gole PR et al.

\section{CONCLUSION}

Colloid goitre is a more common benign thyroid selling. Thyroid disorders are more common in females. Most common in the age group of 25-40 yrs. Papillary carcinoma is most commonly seen. The high incidence of colloid goitre and increased incidence of follicular carcinoma could be due to high endemicity of iodine deficiency in Srikakulam district and surrounding areas.

\section{REFERENCES}

1. Afroze N, Kayani N, Hasan SH. Role of FNAC in the diagnosis of palpable thyroid lesions. Indian Journal of Pathology and Microbiology 2002;45(3):241-6.

2. Rojeski MT, Gharib H. Nodular thyroid disease. Evaluation and management. N Eng J Med 1985;313(7):428-36.

3. Gregory PS, Orlo HC, Jon A, et al. Malignancy of thyroid. Schwartz principles of Surgery. 7 th edn. Mc Graw Hill publishers 1999;164(6);1661-711.

4. Layfield LJ, Cibas ES, Gharib H, et al. Thyroid aspiration cytology: current status. CA Cancer J Clin 2009;59(2):99110.

5. Ogilvie JB, Piatigorsky EJ, Clark OH. Current status of fine needle aspiration for thyroid nodules. Adv Surg 2006;40:223-38

6. Polyzos SA, Kita M, Avramidis A. Thyroid nodules stepwise diagnosis and management. Hormones (Athens) 2007;6(2):101-19.

7. Gardner HA, Ducatman BS, Wang HH. Predictive value of fine-needle aspiration of the thyroid in the classification of follicular lesions. Cancer 1993;71(8):2598-603.

8. Sengupta A, Pal R, Kar S, et al. Clinico-pathological correlation of incidentally revealed thyroid swelling in Bihar, India. Indian Journal of Pharmacy and Allied Sciences 2012;4(1):51-5. 
9. Gole PR, Kamath BS, Madhava K. Diagnostic accuracy of fine needle aspiration cytology in nodular goitres with clinico-pathological correlation. Int Surg J 2016;3(3): 1077-81.

10. Handa U, Garg S, Mohan $\mathrm{H}$, et al. Role of fine needle aspiration cytology in diagnosis and management of thyroid lesions: a study on 434 patients. Journal of Cytology 2008;25(1):13-7.
11. Babu SBK, Raju R, Radhakrishnan S. Correlation of fine needle aspiration cytology (FNAC) with histopathology in the diagnosis of thyroid swellings. Int Surg J 2016;3: 1437-41. 